\title{
ADJUVANT TREATMENT OF GASTRIC CANCER IN A LONG TERM FOLLOW-UP
}

\author{
Tratamento adjuvante no câncer gástrico em seguimento a longo prazo \\ Miriam Honda FEDERICO, Bruno ZILBERSTEIN, Ivan CECCONELLO, Carlos Eduardo JACOB, \\ Cláudio BRESCIANI, Osmar KENJI, Donato MUCERINO, Fábio LOPASSO
}

ABCDDV/634

Federico MH, Zilberstein B, Cecconello I, Jacob CE, Bresciani C, Kenji O, Mucerino D, Lopasso F. Adjuvant treatment of gastric cancer in a long term follow-up. ABCD Arq Bras Cir Dig 2009;22(1):25-8

ABSTRACT - Background - Advanced gastric cancer carries a poor-prognosis. The best extent of the node dissection and the value of postoperative adjuvant treatments remain open questions. Aim - To study the efficacy of adjuvant chemoradiation and the prognostic value of some clinicopathological variables in gastric cancer previously submitted to surgery. Methods - Retrospective single institution study of 69 patients with histological diagnoses of gastric adenocarcinoma, consecutively submitted to radical surgery with curative intent in a five years period. Lymph node dissection was either D1 or D2 at the surgeon's description. All patients were submitted to adjuvant chemoradiation according to MacDonald et al. ${ }^{2}$. Treatment discontinuation and early deaths were considered as serious toxic events. Clinical-pathological variables (the extent D level of the node dissection, $\mathrm{T} / \mathrm{N}$-stage, histological subtype, margin status, number of the dissected nodes) were correlated to the results. Overall survival was estimated according to the Kaplan-Meier method and the curves were compared by the log-rank test. Results - Patients characteristics: 48 male/21 female, median age 56,4 y (30-79). In 25 patients, the extent of node dissection was D1, in 41 was D2 and D0 in 3. Staging (n): T2 (16); T3 (49); T4 (4); No (11); N1 (29); N2 (20); N3 (8); Nx (1). Histological subtype: intestinal (45), diffuse (19) and unknown (5). Margins were free in 57 patients, the median number of dissected nodes was $31(0-120)$. They were treated with linear acelerator $6 \mathrm{MV}$ photons, AP/PA fields with $45 \mathrm{~Gy}$ in 5 weeks in $90 \%$ of the patients and the treatment was done in a mean time of 19,2 weeks. In the median follow-up of 19,3mo (8-52,5mo), 52 patients with more than 24 months of follow-up occurred 38 deaths. The median overall survival for all patients was 22,2 months. Seven (10\%) patients presented serious toxic events and treatment was discontinued. Six $(8,6 \%)$ refused to continue the treatment. The acute toxicity was predominantly gastrointestinal (63), neurological (2), hematological (3), stroke (1). Toxicity was considered GI/GII (52), GIII (10) and GIV (1). Recurrences were local (6); loco-regional (2); local and distant (5); regional (9); regional and distant (2) and only distant (4). There were two patients with progression of the disease and 11 were lost of the follow-up (16\%). Twenty eight (40,5\%) were alive without disease. In the 52 patients with longer follow-up the Kaplan Mayer analysis showed: better overall survival was observed in those patients presenting T2 versus T3/T4 tumors (not reached vs 17,3 mo, HR $0,35,95 \% \mathrm{CI}, P=0,03)$, N0N1 vs N2/N3 tumors ( $32,7 \mathrm{mo}$ vs $14,5 \mathrm{mo}, P=0,0041)$ and free vs compromised surgical margins $(25,7$ vs 17,2 mo, $P=0,03)$. No difference in either T $(P=0,430$, Fisher exact test), N-stage $(P=0,077)$, or overall survival $(27,1 \mathrm{mo}$ vs $17,3 \mathrm{mo}, P=0,28)$ were detected between patients submitted to D1 or D2 dissections. Conclusions - In this high-risk population of gastric cancer submitted to adjuvant chemoradiation, D2 dissection was not superior to D1 when chemoradiation was administered, in spite of the retrospective nature of these data and the low number of studied patients. Patients with compromised surgical margins have a very poor prognosis and the addition of chemoradiation seems not improve the survival of these patients.

HEADINGS - Gastric neoplasm. Adenocarcinoma. TNM classification. Chemoradiation. Adjuvant therapy.

\section{INTRODUCTION}

Carcinoma of the stomach is the second most common malignancy in the world, and surgical resection remains the only curative treatment option. However, local or regional recurrence in the gastric or tumor bed, the anastomosis, or regional lymph nodes occurs in 40 to $65 \%$ of patients after gastric resection with curative intent. Large retrospective series from Japan of radical gastrectomy with level-2 extended lymphadenectomy (D2 resections) have shown impressive 5-years survival rates ${ }^{5}$. However, when benefit of D2 over conventional D1 resections was tested prospectively in randomized trials ${ }^{1}$, it was observed

From the University of São Paulo School of Medicine, Department of Gastroenterology, Digestive Surgery Division, São Paulo, SP, Brasil

Correspondence: Ivan Cecconello, e-mail: cecconello@terra.com.br a significant increase in post-operative morbidity and mortality ( $43-46 \%$ and $10-13 \%$ respectively) with no survival benefit. Therefore, the extent of lymphadenectomy to achieve the optimal result is controversial, and there is no worldwide consensus.

Understanding patterns of relapse after resection is paramount for designing therapeutic strategies. Clinical, re-operation, and autopsy series demonstrate a high incidence of loco-regional and distant relapses after $\mathrm{R} 0$ resection. Local relapse was only evidence of cancer in $29 \%$ of the re-operative patients and as any component of relapse in $88 \% \%^{6}$. The frequency of such relapses makes regional radiation an attractive possibility for adjuvant therapy.

A US Intergroup trial (INT-116) indicated a therapeutic benefit to post-gastrectomy chemoradiation, primarily because of a reduction in the high loco-regional recurrence rate of gastric cancer ${ }^{3,4}$. However, this intergroup trial INT116 , was characterized by a node-positive rate of $85 \%$, a limited lymphadenectomy extent $(<\mathrm{D} 1,54 \%$; D1, $36 \%$; 
$\mathrm{D} 2,10 \%$ ) and an overall recurrence rate in the control group of approximately $75 \%$. Despite the lack of survival benefit to gastrectomy with $\mathrm{D} 2$ dissection in two randomized studies, the possibility of this approach decrease loco-regional recurrence was demonstrated in these two studies. So, the doubt persists if the result of the INT-116 could be applied to patients with an extended lymphadenectomy. In Brazil, the D2 lymphadenectomy is the most common approach used to treat cancer of stomach.

The aim of this study was to describe the experience of the institution in the treatment of patients with predominantly D2 lymphadenectomy following the INT-116 recommendations.

\section{METHODS}

This study relates the experience in the treatment of gastric cancer treated in the period of October/2001 to April/2005 in a single institution. Special attention was focused in patients treated with curative intention following the recommendations of Macdonald's protocol' ${ }^{2}$. This is a retrospective study of 69 patients with histological diagnoses of adenocarcinoma of the stomach or gastroesophageal junction, consecutively submitted to radical surgery with curative intent. Limph node dissection was either D1 or D2 at the surgeon's description. All patients were submitted to adjuvant chemoradiation ${ }^{2}$. It was included patients with stage IB to IVM0 according to the 1988 staging criteria of the American Joint Commission on Cancer, a performance status of 2 or lower according of the Southwest Oncology Group and adequate function of major organs.

After undergoing gastrectomy, patients received post-operative combination of fluorouracil plus leucovorin and localregional radiation. Chemotherapy (Fluorouracil, $425 \mathrm{mg}$ per square meter of body-surface area per day, and leucovorin, $20 \mathrm{mg}$ per square meter per day, for 5 days) was initiated on day 1 and was followed by chemoradiotherapy beginning 28 days after the start of the initial cycle of chemotherapy.

Chemoradiotherapy consisted of $45 \mathrm{~Gy}$ of radiation at $1,8 \mathrm{~Gy}$ per day, five days per week for five weeks, with fluorouracil (400mg per square meter per day) and leucovorin (20mg per square per day) on the first four and the last three days of radiotherapy. On month after the radiotherapy, two five-day cycles of fluorouracil (425mg per square meter per day) plus leucovorin (20mg per square meter per day) were given one month apart. The dose of drugs were reduced or suspended in patients who had grade 3 or 4 toxic effects.

The radiotherapy was delivered to the tumor bed and regional nodes with $2 \mathrm{~cm}$ of margins. The tumor bed was defined by pre-operative computed tomographic (CT) imaging. Perigastric, celiac, local para-aortic, splenic, hepatoduodenal or hepatic portal, and pancreaticoduodenal lymph nodes were included in the radiation fields of all patients. In patients with tumors of the gastroesophageal junction, the paracardial and paraesophageal lymph nodes were included in the radiation fields. The dose $45 \mathrm{~Gy}$ was delivered in 25 fractions, five days per week and a boost of 9Gy to a reduced lat/lat field was programmed to patients with positive margins. The planning was conventional
(2D) in a simulator machine with renal contrast IV and at least two thirds of one kidney was spared from the field of radiation. Radiation was delivered with Cobalt machine $(5 \%)$ or linear accelerator $6 \mathrm{MV}$ to $15 \mathrm{MV}$ photons $(95 \%)$. The doses limit tolerance of kidney, small bowel and liver were respected. Treatment discontinuation and early deaths were considered as serious toxic events.

Follow-up occurred at three-month intervals for two years, then at six-month intervals for three years. Follow-up consisted of physical examination, a complete blood count, liver function testing, chest radiography, and CT scanning and endoscopies as clinically indicated. The site and the date of the first relapse and the date of death, if the patient died, were recorded.

Overall survival was estimated according to the KaplanMeier method and curves were compared by the long-rank test. Clinical-pathological variables (the extent [D level] of the nodes dissection, $\mathrm{T} / \mathrm{N}$-stages, histological subtype, margin status, number of dissected nodes) were analyzed. All eligible patients were included in the analysis of survival and relapsefree survival according to the intention-to-treat principle.

The sites of relapse were considered as follow: 1) local: if relapse was detected in the surgical anastomosis, residual stomach, or gastric bed; 2) regional: if relapse was detected in the peritoneal cavity (including the liver, intrabdominal lymph nodes, and peritoneum; 3 ) distant: if the metastases occurred outside the peritoneal cavity.

\section{RESULTS}

In 25 patients, the extent of node dissection was D1, in 41 patients was D2 and in three D0. Eleven patients had their tumors in esophageal junction (16\%). The histological subtypes observed were: intestinal (45), diffuse (19) and unknown (5). Margins were free in 57 patients and the median number of dissected nodes was 31 (0-120 nodes). Others characteristics and stage observed are described in Table 1.

TABLE 1 - Characteristics of the patients $(n=69)$

\begin{tabular}{lll}
\hline Characteristics & Dissection D1 & Dissection D2 \\
\hline T stage (\%) & & \\
T1 or T2 & 8 & 9 \\
T3 & 17 & 31 \\
T4 & 1 & 2 \\
N stage (\%) & & \\
N0 & 3 & 2 \\
N1 & 15 & 12 \\
N2 & 5 & 16 \\
N3 & 2 & 6 \\
T2N0 & 2 & 1 \\
T2N1 & 5 & 7 \\
T2N2 & 1 & 0 \\
T3N0 & 1 & 6 \\
T3N1 & 9 & 4 \\
T3N2 & 2 & 17 \\
T3N3 & 2 & 5 \\
T4N1 & 0 & 1 \\
T4N2 & 1 & 0 \\
T4N3 & 0 & 1 \\
\hline
\end{tabular}

Radiation was delivered with linear acelerator (6MV fotons), dose $45 \mathrm{~Gy}$ and $\mathrm{AP} / \mathrm{PA}$ technique in the majority of patients $(97 \%)$. Of the 69 patients that received the treatment, seven (10\%) patients presented serious toxic events 
(2 hematologic, 3 gastrointestinal, 1 DPD, 1 vascular) and treatment was discontinued; two (3\%) patients needed reduction of the chemotherapy dosage because hematological toxicity; six (9\%) refused to continue the treatment and two $(3 \%)$ developed progression of the disease. The acute toxicity was considered G(I)/G(II) of Radiation Therapy Oncology Group (RTOG) acute toxicity classification in 52 patients, $\mathrm{G}(\mathrm{III})$ in 10 and $\mathrm{G}(\mathrm{IV})$ in one patient. The description of the toxicity observed is listed in Table 2.

TABLE 2 - Toxic effects of chemoradiotherapy $(n=69)$

\begin{tabular}{lccc}
\hline Type of toxic effect & N (\%) & $\begin{array}{c}\text { N (\%) } \\
\text { Toxicity grade III }\end{array}$ & $\begin{array}{c}\text { N (\%) } \\
\text { Toxicity grade IV }\end{array}$ \\
\hline Gastrointestinal and hematologic & 63 & 1 & 0 \\
Gastrointestinal & 53 & 6 & 0 \\
Hematologic & 10 & 3 & 0 \\
Neurologic & 2 & 0 & 0 \\
Vascular & 1 & 0 & 1 \\
Lung related & 1 & 0 & 0 \\
\hline
\end{tabular}

Eleven (16\%) patients completed the treatment but were lost of the follow-up and were excluded of the overall survival analysis. Twenty eight (40,5\%) were alive without disease. Relapses were reported in 29/69 (42\%) patients. It was recorded information on the site of the first relapse only (Table 3). Exclusive loco-regional recurrence occurred in $24,6 \%$ of patients and was associated with distant relapses in $11 \%$.

TABLE 3 - Description of the sites of recurrence $(n=58)$

\begin{tabular}{ll}
\hline Site of recurrence (\%) & Site - N ( ) \\
\hline Local 6/69 (8,6\%) & Gastric bed (3) \\
& Anastomosis (3) \\
Regional 9/69 (13\%) & Peritoneum and limph nodes (4) \\
& Hepatic (4) \\
& Intestinal (1) \\
Local and regional 2/69 (3\%) & Anastomosis and hepatic (1) \\
& Anastomosis and peritoneum (1) \\
Local and distant 5/69 (7\%) & Gastric bed and lung (3) \\
& Gastric bed and fossa (2) \\
Regional and distant 3/69 (4\%) & Peritoneum and lung (1) \\
& Hepatic and lung (1) \\
& Limph nodes and lung (1) \\
Distant 4/69 (6\%) & Fossa (1) \\
& Fossa and SNC (1) \\
Total 29/69(42\%) & Lung (2) \\
\hline
\end{tabular}

\section{Overall and relapse-free survival}

In 69 patients, the median follow-up was 19,3 months (mo) range 8 to $52 \mathrm{mo}$. In 52 patients with longer follow-up $(>24 \mathrm{mo})$, the Kaplan-Mayer analysis was performed and the median survival was 22,2 (SE 4,8) mo.

Better overall survival was observed in those patients presenting T2 vs T3/T4 (not reached vs. 17,3 mo $P=0,03$ ), N0/N1 vs N2N3 tumors $(32,7$ mo vs 14,5 mo $P=0,0041)$ and free vs compromised surgical margins $(25,7 \mathrm{mo}$ vs. $17,2 \mathrm{mo}, P=0,077)$, or overall survival $(27,1 \mathrm{mo}$ vs 17,3 mo, $P=0,28$ ) were detected between patients submitted to $\mathrm{D} 1$ or $\mathrm{D} 2$ dissections.

\section{DISCUSSION}

Although gastric carcinoma is frequent, it's treatment is always a challenge. Surgery remains an important step, but sometimes adjuvant therapy is necessary to be added. The surgery in itself can take out all the visible involvement, but local or regional recurrence occurs in half of the patients. The best results with surgical treatment comes from Japan with excellent rates with D2 resections. But this results were not equally reached by occidental surgeons ${ }^{1}$ and more, with a significant increase in post-operative morbidity and mortality with no survival benefit. Therefore, more evidences in randomized trials must be done to confirm it's real advantage.

Therapeutic benefit to post-gastrectomy chemoradiation has the intention to reduce loco-regional recurrence rate, but doubt persists if the result in long follow-up. This was the reason why this study was done.

Although long follow-up is difficult to be done in Brazil, this study got expressive number of patients with more than two years. As expected, the ones presenting T2, N0/N1 and free tumor surgical margins presented the best results.

A good aspect of this paper was that it was done based in a retrospective single institution including 69 patients consecutively submitted to radical surgery with curative intent in the period of five years. They were operated by the same surgical team and had almost in all patients the opportunity to use the same protocol of chemoradiation.

The surgical dilemma is always to offer the best result with minor morbid-mortality, accomplished by better quality of life of the patient. So, D2 and D1 represent different possibilities of complications. The strategy of using one or another, must be in surgeons' mind at the moment when the abdomen is opened. Now a days, it's not proved the superiority of D2 in relationship to D1 when chemoradiotherapy is associated.

Therefore, cautiousness is mandatory to offer the possible treatment to the patient, having in mind that even not doing the best in curative intention, is the most reasonable form of treatment to be done in that moment.

\section{CONCLUSIONS}

In this high-risk population of gastric cancer submitted to adjuvant chemoradiation, D2 dissection was not superior to D1 when chemoradiation was administered, in spite of the retrospective nature of these data and the low number of studied patients. Patients with compromised surgical margins have a very poor prognosis and the addition of chemoradiation seems not improve the survival of these patients. 
Federico MH, Zilberstein B, Cecconello I, Jacob CE, Bresciani C, Kenji O, Mucerino D, Lopasso F. Tratamento adjuvante no câncer gástrico em seguimento a longo prazo. ABCD Arq Bras Cir Dig 2009;22(1):25-8

RESUMO - Racional - Câncer gástrico avançado é sempre acompanhado de pobre prognóstico. A melhor forma de ser realizada a linfadenectomia e o valor da radioquimioterapia adjuvante ainda estão em tela de juízo. Objetivo - Estudar a eficácia da terapia adjuvante e o valor prognóstico de algumas variáveis clínico-patológicas nos pacientes submetidos à ressecção cirúrgica de seus tumores. Métodos - Estudo retrospectivo de uma única instituição hospitalar incluindo 69 pacientes com diagnóstico histológico de adenocarcinoma gástrico consecutivamente submetidos à operação radical com intenção curativa no período de cinco anos. Linfadenectomia foi tanto D1 como D2 e em todos os pacientes foi aplicado o protocolo quimioradioterápico proposto por Macdonald et al. ${ }^{2}$. Interrupção do tratamento bem como mortes precoces foram consideradas eventos tóxicos sérios. Variáveis clínico-patológicas (extensão do D, estadiamento T/N, subtipos histológicos e número de linfonodos ressecados), foram correlacionados com os resultados. A sobrevida total foi estimada de acordo com o método de Kaplan-Meier. Resultados - Foram 48 homens e 21 mulheres, com idade média de 56,4 anos. Em 25 pacientes a extensão da linfadenectomia foi D1; em 41, D2 e em 3, D0. O estadiamento T2 foi em 16 pacientes; T3 em 49; T4 em 4; N0 em 11; N1 em 29; N2 em 20; N3 em 8; Nx em 1. O subtipo histológico intestinal ocorreu em 45; o difuso em 19 e desconhecido em 5. Em 57 pacientes as margens estavam livres de tumor e foram ressecados em média 31 linfonodos. Foram tratados por acelerador linear $6 \mathrm{MV}$, AP/PA campos com 45Gy em cinco semanas em 90\% dos casos com média de tratamento de 19,2 semanas. No tempo médio de seguimento de 19,3 meses, entre 52 pacientes com mais de 24 meses foram observadas 38 mortes. O tempo médio geral de sobrevida do grupo como um todo foi de 22,2 meses. Sete $(10 \%)$ apresentaram eventos tóxicos sérios e o tratamento foi interrompido. Seis $(8,6 \%)$ recusaram a continuar no grupo de estudo. Toxicidade foi considerada GI/GII em 52, GIII em 10 e GIV em 1. Ocorreram 6 recidivas locais, duas loco-regionais, locais e à distância em 5, regionais em 9 , regionais e à distância em 2 e somente à distância em 4 . Dois pacientes progrediram em sua doença e em 11 perdeu-se o seguimento (16\%). Vinte e oito (40,5\%) estavam vivos e sem doença até o encerramento da pesquisa. Em 52 com seguimento mais longo, a análise estatística mostrou que a melhor sobrevida se deu naqueles com T2 vs T3/T4, N0/N1 vs N2/N3 e com margens livres. Não houve diferença estatística entre os estadiamentos $\mathrm{T}, \mathrm{N}$ ou o tempo de sobrevida quando comparou-se estes indicadores com o procedimento cirúrgico aplicado (D1 ou D2). Conclusões - Nos pacientes com tumores avançados do estômago submetidos à quimioradioterapia adjuvante, a dissecção D2 não foi superior à D1 nas variáveis estudadas. Naqueles com comprometimento das margens cirúrgicas o prognóstico é muito pobre e a adição de terapia adjuvante parece não melhorar a sobrevida desses pacientes.

DESCRITORES - Neoplasia gástrica. Adenocarcinoma. Classificação TNM. Quimioterapia. Radioterapia. Terapia adjuvante.

\section{REFERENCES}

1. Kodera E, Fujiwara M, Ito Y, Ohashi N, Nakayama G, Koike M, Nakao A. Radical surgery for gastric carcinoma: it is not an issue of whether to perform D1 or D2. Dissect as many lymph nodes as possible and you will be rewarded. Acta Chir Belg. 2009 Jan-Feb;109(1):27-35.

2. MacDonald JS, Smalley SR, Benedetti J, et al. Chemoradiotherapy after surgery compared with surgery alone for adenocarcinoma of the stomach or gastroesophageal junction. N Engl J Med 2001;345:725-730

3. Shah MA. Recent developments in the treatment of gastric carcinoma. Curr Oncol Rep. 2002 May;4(3):193-201.
4. Van Laethem JL, Demols A. Adjuvant therapy in gastric and cardia cancer: should we irradiate? Curr Opin Oncol. 2006 Jul;18(4):381-5

5. Vrba R, Neoral C, Aujeský R, Malý T, Lovecek M. Gastric carcinoma surgery outcomes during 2004-2008. Rozhl Chir. 2009 Feb;88(2):50-4.

6. Matsuzaki WS, Cecconello I, Gama-Rodrigues JJ, KubotaT, Kitajima M. Valor preditivo da quimiosesensibilidade in vitro na quimioterapia do câncer gástrico avançado. Arq Bras Cir Dig. 2003;16(3):111-5

Fonte de financiamento: não há Conflito de interesse: não há Recebido para publicação: 05/08/2008 Aceito para publicação: 03/01/2009 